Animal Health Research Institute,

Assiut Regional Laboratory.

\title{
BACTERIOLOGICAL STUDIES ON ANAEROBIC BACTERIA CAUSING HEPATIC AFFECTIONS IN AGED BUFFALOES WITH REFERENCE TO ITS PUBLIC HEALTH HAZARD
}

(With 5 Tables)

By

\section{S.M. SAYED; H.H. ESSA; N.H. MAKAR; O.A. SADEK and A.M. MANAA}

(Received at 15/8/2010)

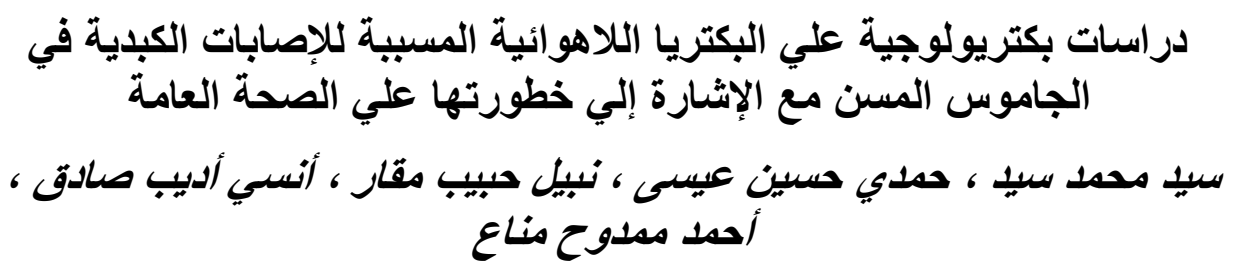

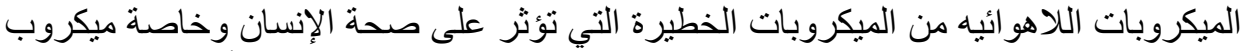

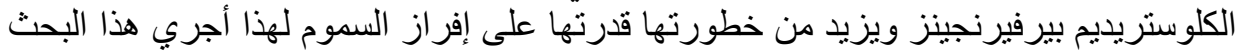

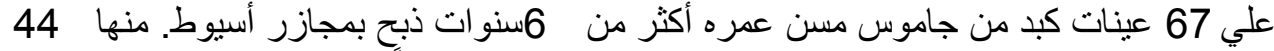

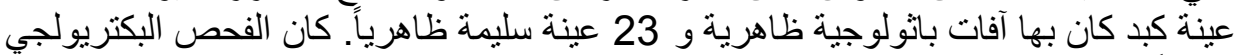

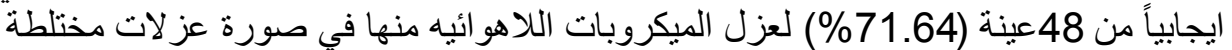

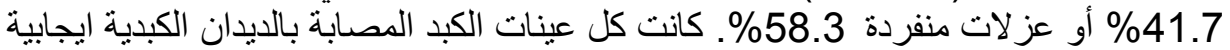

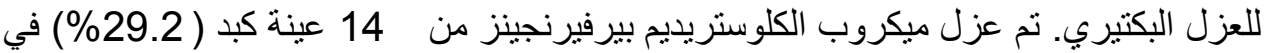

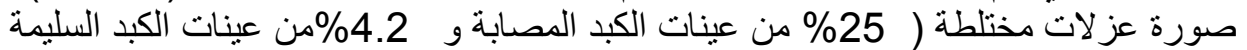

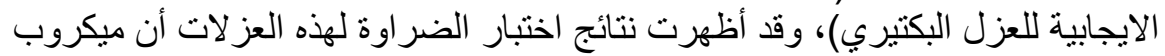

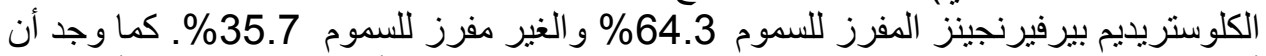

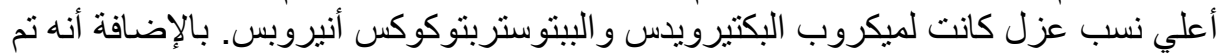

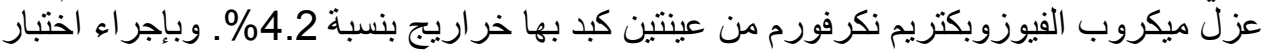

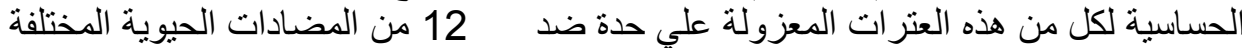

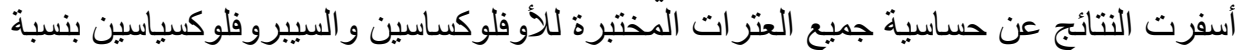

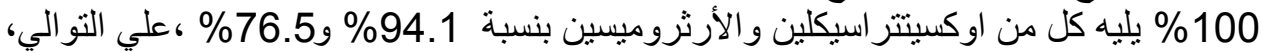

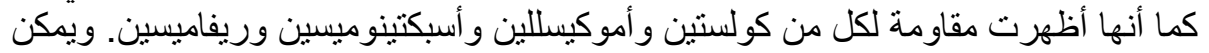

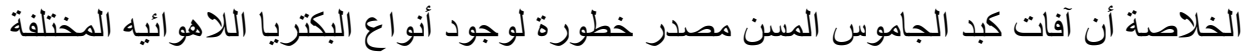
فيها وبخاصة عندما تكون مصابة بالديدان الكبدية.

\section{SUMMARY}

Anaerobic bacteria are of great concern to the food industry, especially Clostridium perfringens that produce exotoxins. The present study was per- 
formed on 67 liver samples from aged female buffaloes (over 6 years old) slaughtered in the slaughter houses in Assiut Governorate, Egypt. Fortyfour liver samples showed gross hepatic lesions and twenty-three samples were apparently normal liver. Bacteriological examination of these liver samples revealed that 48 samples $(71.64 \%)$ were positive for anaerobic bacterial isolation, in mixed infection $41.7 \%$ and in single infection $58.3 \%$. All Fasciola infected livers were positive for anaerobic bacterial isolation. Clostridium perfringens was isolated in mixed form with incidence $29.2 \%$, 14 out of 48 samples positive for anaerobic culture, (25\% and $4.2 \%$ from liver samples showed hepatic affections and normal livers, respectively). The Pathogenicity of the isolated Clostridium perfringens in mice revealed that $64.3 \%$ and $35.7 \%$ were toxigenic and non-toxigenic, respectively. The most prevalent anaerobic isolates were Bacteroides spp. and Peptostreptococcus anaerobius either in single or mixed form. In addition Fusobacterium necrophorum was isolated from two liver abscesses in a single form (4.2\%). Antimicrobial susceptibility testing of the most prevalent isolates, with 12 antibiotics, revealed their sensitivity $100 \%$ to Ofloxacin and $\mathrm{Ci}$ profloxacin followed by Oxytetracycline $(94.1 \%)$ and Erythromycin (76.5\%). All tested bacterial isolates showed resistance to Colistin, Amoxicillin, Spectinomycin and Rifamycin. It can be concluded that livers of slaughtered aged female buffaloes considered as hazardous source of mixed anaerobic bacteria especially which are infected with Fasciola.

Key word: Buffalo, anaerobic bacteria, liver.

\section{INTRODUCTION}

Liver is considered the most important organ for health production and reproduction. Liver infection is an important disease that affects all kinds of meat producing animals, this lead to great losses to livestock production and national income due to condemnation of great numbers of livers in slaughterhouses (Durham et al., 2003; Sayed et al., 2008). Livers of slaughtered aged female buffaloes were considered as hazardous source of mixed different bacterial species (Sayed et al., 2008). Anaerobic microorganisms in single or mixed forms were identified and found to play a role in hepatic affection of buffaloes as Fusobacterium necrophorum; Clostridium sordellii and Clostridium perfringens (Zaki et al., 2000). $\mathrm{Cl}$. perfringens is an anaerobe responsible for a wide range of diseases in animals and humans (Niilo, 1986; Mohamed et al., 2004).

Clostridia are widely distributed in nature and are found in soil as well as in fresh water and marine sediments throughout the world (Onderdonk and Allen, 1994). 
The presence of the organism in soil has made it as an important soil pathogen, especially for those species that cause infections. The ecological factors usually play a very important role in the development of clostridial soil borne diseases (Siefert et al., 1996). The clinical pictures of $\mathrm{Cl}$. perfringens in animals were summarized into three forms; (A) intestinal diseases, (B) muscle diseases and (C) liver diseases. The potent exotoxins produced by the $\mathrm{Cl}$. perfringens are the main way for its pathogenicity in animals and human (Mai and Ezz El-Deen 2003). Enterotoxaemia is a main syndrome caused by $\mathrm{Cl}$. perfringens and characterized by high fatality rate, hemorrhagic enteritis and diarrhea (Manecta et al., 2001)

$\mathrm{Cl}$. perfringens remains a major cause of food borne illness worldwide and is continuing concern to the food service industry (Stringer et al., 1980). ICMSF (International Commission on Microbiological Specification for Food, 1986) considered that $\mathrm{Cl}$. perfringens gain access during processing of food service operations. Clostridia have been incriminated in many anaerobic infection, they produce various toxins that damage tissues of the nervous system. The most common clostridial infections are shortlived and relatively mild food poisoning, but may cause inflammation that sometimes destroys the wall of the large and small intestine, a condition called necrotizing enteritis (Kamakaraj et al., 1998; Quinn, et al., 2002). Among food borne pathogens, $\mathrm{Cl}$. perfringens enterotoxin is an important virulence factor causing several illnesses in both humans and animals (Yanny and Shalaby, 2003). Cl. perfringens can grow at low temperature below $15{ }^{\circ} \mathrm{C}$ but the growth is slow. The growth rate is related to $\mathrm{pH}$ and medium as well as temperature, so that the $\mathrm{Cl}$. perfringens grows slower in media at $\mathrm{pH} 5.8$ than at $\mathrm{pH}$ 7.2. Germination of clostridia spores has been observed at $5{ }^{\circ} \mathrm{C}$ (Hobbs and Gilbert, 1969).

$\mathrm{Cl}$. perfringens is a large gram positive, anaerobic rod that produces endo- spores. These endospores allow survival outside the body for long periods. They are highly resistant to many chemical and physical factors including desiccation and heat. The most heat resistant spores can survive at temperature of $100{ }^{\circ} \mathrm{C}$ for $60 \mathrm{~min}$. and so remain viable after many types of cooking. $\mathrm{Cl}$. perfringens is the type commonly implicated in food poisoning. In food poisoning a large dose of vegetative cells are ingested with the contaminated food. This large number of bacteria alters the normal intestinal flora multiply briefly and then sporulates in the intestine. During sporulation, the enterotoxin responsible for the signs of food poisoning is produced (Quinn el al., 2002).

The aim of this work was to investigate the prevalence of anaerobic bacteria in affected and normal livers of aged female buffaloes, the 
antibiogram of the most prevalent these bacterial isolates, as well as pathogenicity of some isolated bacteria in experimental animals.

\section{MATERIALS and METHODS}

\section{MATERIALS:}

\section{1- Samples:}

A total 67 of liver samples (44 liver samples revealed gross hepatic lesions and 23 samples of normal liver) of aged female buffaloes (more than 6 years) were collected from slaughter houses in Assiut Governorate. For bacteriological examination, each sample was collected in a clean sterile plastic bag and transferred directly to the laboratory.

\section{2- Culture media:}

a- Cooked meat medium "Oxoid".

b- Blood agar medium with $7 \%$ sheep blood.

\section{3- Media used for biochemical tests:}

Sugar fermentation (glucose, maltose, sucrose and mannitol), gelatin medium, glucose phosphate broth medium, peptone water, triple sugar iron agar (T. S. I.), urea agar base and solid agar media.

\section{4- Reagents, chemicals and stains used were:}

Kovac's reagents, urea, methyl red, Andrade's indicator, Gram's stain, glucose $1 \%$.

\section{5- Experimental animals:}

Swiss mice were inoculated through tail vein with $0.3 \mathrm{ml}$ of centrifuged supernatant of $48 \mathrm{~h}$. culture of $\mathrm{Cl}$. perfringens. The animals were kept under observation for 72 hours after inoculation (Carter, 1984; Buogo et al., 1995).

\section{6- Gas-pack anaerobic jar "Oxoid":}

It was used for production of anaerobiosis by using disposable hydrogen-carbon dioxide bags with socket.

\section{7- Antimicrobial sensitivity discs:}

It was manufactured by Bioanalyse (Turkey) including; Amoxicillin $(25 \mu \mathrm{g})$; Ciprofloxacin $(5 \mu \mathrm{g})$; Cephalexin $(30 \mu \mathrm{g})$; Cefotaxime $(3 \mu \mathrm{g})$; Colistin $(10 \mu \mathrm{g})$; Erythromycin $(15 \mu \mathrm{g})$; Gentamycin $(10 \mu \mathrm{g})$ Oxytetracycline $(30 \mu \mathrm{g}) ;$ Ofloxacin $(5 \mu \mathrm{g})$; Rifamycin $(30 \mu \mathrm{g})$; Spectinomycin $(100 \mu \mathrm{g})$ and Trimethoprim $(5 \mu \mathrm{g})$.

\section{METHODS:}

\section{1- Isolation and identification of anaerobes:}

The liver samples of aged female buffaloes were subjected to anaerobic bacteriological examination. Two grams of each liver sample were inoculated separately into two sterile cooked meat media tubes. Both inoculated media were incubated anaerobically at $37^{\circ} \mathrm{C}$ for 48 hours. One 
of them was heated in water bath at $75^{\circ} \mathrm{C}$ for 15 minutes, while the other was left unheated. Subcultures from each of 48 hours cultures were streaked on blood agar plates and incubated anaerobically at $37^{\circ} \mathrm{C}$ for 24 hours. Only strict anaerobic isolates were examined and identified for microscopical appearance, culture characters, and motility then transferred to cooked meat medium for the other biochemical tests as described by Koneman et al. (1988).

\section{2- Pathogenicity tests:}

All strains that were identified biochemically as $\mathrm{Cl}$. perfringens were evaluated for the presence of lethal toxin through inoculation into the mice models. Swiss mouse weighing about $50 \mathrm{~g}$. body weights that kept for 15 days was considered as $\mathrm{Cl}$. perfringens free mice and used for the pathogenicity test. $\mathrm{Cl}$. perfringens strains were grown for about 48 hours in cooked meat medium (Oxoid). After centrifugation at 10000-x g for 10 min., $0.3 \mathrm{ml}$ quantities of the supernatant of each strain was injected into the tail vein of two mice and two mice were inoculated with sterile saline as negative control according to Carter (1984) and Buogo et al. (1995).

\section{3- Reisolation of the inoculated organisms was done as mentioned above.}

\section{4- Sensitivity test:}

The most prevalent isolated strains were tested for sensitivity to different chemotherapeutic agents. One $\mathrm{ml}$ of 48 hours broth cultures was spread on the surface of blood agar. Antibiotic sensitivity discs were placed on the surface of seeded agar. Plates were incubated anaerobically at $37^{\circ} \mathrm{C}$ for 24 hours. The sensitivity was judged according to the diameter of clearance zone around the discs (Perelman et al., 1991).

\section{RESULTS}

Detailed obtained results are illustrated in Tables 1-5.

Table 1: Prevalence of anaerobic bacterial positive culture in different hepatic affections and normal livers $(n=67)$.

\begin{tabular}{|c|c|c|c|c|c|}
\hline \multirow{2}{*}{ Examined livers } & \multirow{2}{*}{$\begin{array}{c}\text { Gross hepatic affec- } \\
\text { tions }\end{array}$} & \multicolumn{2}{|c|}{ No. of samples } & \multicolumn{2}{|c|}{$\begin{array}{l}\text { Positive for anaerobic } \\
\text { bacterial culture }\end{array}$} \\
\hline & & No. & $\%$ & No. & $\%$ \\
\hline \multirow[t]{2}{*}{$\begin{array}{l}\text { Liver showing he- } \\
\text { patic affections }\end{array}$} & $\begin{array}{l}\text { 1- Fascioliasis } \\
\text { 2- Hepatitis } \\
\text { 3- Necrosis } \\
\text { 4- Liver abscess }\end{array}$ & $\begin{array}{c}12 \\
23 \\
6 \\
3\end{array}$ & $\begin{array}{c}17.91 \\
34.32 \\
8.96 \\
4.48\end{array}$ & $\begin{array}{c}12 \\
16 \\
4 \\
3\end{array}$ & $\begin{array}{c}17.91 \\
23.88 \\
5.97 \\
4.48\end{array}$ \\
\hline & Total & 44 & 65.67 & 35 & 52.24 \\
\hline \multicolumn{2}{|l|}{ Normal livers } & 23 & 34.33 & 13 & 19.40 \\
\hline \multicolumn{2}{|c|}{ Total examined } & 67 & 100 & 48 & 71.64 \\
\hline
\end{tabular}


Table 2: Anaerobic microorganisms isolated from liver samples positive for bacterial culture $(n=48)$.

\begin{tabular}{|c|c|c|c|c|c|c|}
\hline \multirow{2}{*}{$\begin{array}{l}\text { Hepatic } \\
\text { lesions }\end{array}$} & \multicolumn{6}{|c|}{ Bacterial isolates } \\
\hline & Single infection & No. & $\%$ & Mixed infection & No. & $\%$ \\
\hline \multirow{3}{*}{ Fasciola } & Bacteroides spp. & 5 & 10.4 & $\begin{array}{l}\text { Cl. perfringens \& } \\
\text { Bacteroides spp. }\end{array}$ & 1 & 2.1 \\
\hline & \multirow{2}{*}{$\begin{array}{l}\text { Peptostreptococcus } \\
\text { anaerobius }\end{array}$} & \multirow{2}{*}{4} & \multirow{2}{*}{8.3} & $\begin{array}{c}\text { Cl. sordellii \& } \\
\text { Bacteroides } \text { spp. }\end{array}$ & 1 & 2.1 \\
\hline & & & & $\begin{array}{l}\text { Cl. perfringens \& Cl. sordellii } \\
\text { \& Bacteroides spp. }\end{array}$ & 1 & 2.1 \\
\hline \multirow{3}{*}{ Hepatitis } & Bacteroides spp. & 2 & 4.2 & $\begin{array}{l}\text { Cl. perfringens \& Bacteroides } \\
\text { spp. }\end{array}$ & 2 & 4.2 \\
\hline & \multirow{2}{*}{$\begin{array}{l}\text { Peptostreptococcus } \\
\text { anaerobius }\end{array}$} & \multirow{2}{*}{6} & \multirow{2}{*}{12.5} & $\begin{array}{c}\text { Cl. perfringens \& Peptostrepto- } \\
\text { coccus anaerobius }\end{array}$ & 4 & 8.3 \\
\hline & & & & $\begin{array}{c}\text { Bacteroides spp. \& } \\
\text { Peptostreptococcus anaerobius }\end{array}$ & 2 & 4.2 \\
\hline \multirow[b]{2}{*}{ Abscess } & F. necrophorum & 2 & 4.2 & \multirow[b]{2}{*}{ - } & \multirow[b]{2}{*}{ - } & \multirow[b]{2}{*}{ - } \\
\hline & $\begin{array}{l}\text { Peptostreptococcus } \\
\text { anaerobius }\end{array}$ & 1 & 2.1 & & & \\
\hline Necrosis & - & - & - & $\begin{array}{l}\text { Cl. perfringens \& } \\
\text { Bacteroides spp. }\end{array}$ & 4 & 8.3 \\
\hline \multirow{5}{*}{$\begin{array}{c}\text { Normal } \\
\text { liver } \\
\text { Samples }\end{array}$} & Bacteroides spp. & 7 & 14.6 & \multirow{2}{*}{$\begin{array}{c}\text { Bacteroides spp. \& } \\
\text { Peptostreptococcus anaerobius }\end{array}$} & \multirow{2}{*}{2} & \multirow[b]{2}{*}{4.2} \\
\hline & \multirow{4}{*}{$\begin{array}{l}\text { Peptostreptococcus } \\
\text { anaerobius }\end{array}$} & \multirow[t]{4}{*}{1} & \multirow[t]{4}{*}{2.1} & & & \\
\hline & & & & Cl. perfringens \& Bacteroides & 1 & 2.1 \\
\hline & & & & Cl. sordellii \& Bacteroides spp. & 1 & 2.1 \\
\hline & & & & Cl. perfringens \&Cl. sordellii & 1 & 2.1 \\
\hline & Total & 28 & 58.3 & & 20 & 41.7 \\
\hline
\end{tabular}

Table 3: Incidence of anaerobic bacteria isolates recovered from the examined liver samples $(n=69)$.

\begin{tabular}{|c|c|c|}
\hline Anaerobic bacterial isolates & No. & $\%$ \\
\hline Bacteroides spp & 29 & 42.02 \\
\hline Peptostreptococcus anaerobius & 20 & 28.99 \\
\hline Clostridium perfringens & 14 & 20.29 \\
\hline Clostridium sordellii & 4 & 5.80 \\
\hline Fusobacterium necrophorum & 2 & 2.90 \\
\hline Total & 69 & 100 \\
\hline
\end{tabular}

Table 4: Incidence of toxigenic and non-toxigenic Clostridium perfringens in the examined livers samples.

\begin{tabular}{|c|c|c|c|c|c|c|}
\hline $\begin{array}{c}\text { No. of examined } \\
\text { liver samples }\end{array}$ & \multicolumn{2}{|c|}{$\begin{array}{c}\text { Positive for } \\
\text { Cl. perfringens }\end{array}$} & \multicolumn{2}{c|}{$\begin{array}{c}\text { Toxigenic } \\
\text { Cl. perfringens }\end{array}$} & \multicolumn{2}{c|}{$\begin{array}{c}\text { Non-toxigenic } \\
\text { Cl. perfringens }\end{array}$} \\
\hline \multirow{2}{*}{67} & No./67 & $\%$ & No./14 & $\%$ & No./14 & $\%$ \\
\cline { 2 - 7 } & 14 & 20.9 & 9 & 64.3 & 5 & 35.7 \\
\hline
\end{tabular}


Table 5: The percentage of in vitro antimicrobial susceptibility pattern of some frequent isolates tested against different antibiotics.

\begin{tabular}{|c|c|c|c|c|c|c|c|c|c|c|c|c|c|}
\hline \multirow[t]{2}{*}{ Isolated microorganisms } & \multirow[t]{2}{*}{ 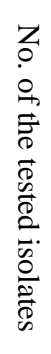 } & 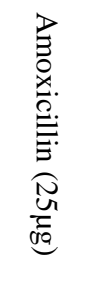 & 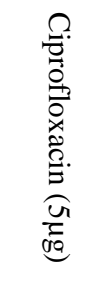 & 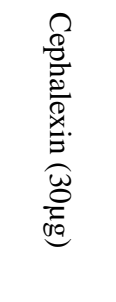 & 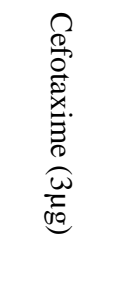 & 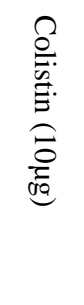 & 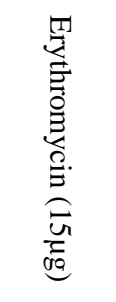 & 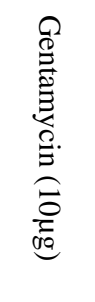 & 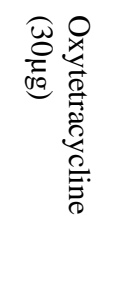 & 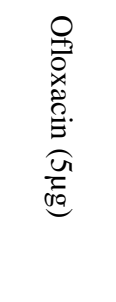 & 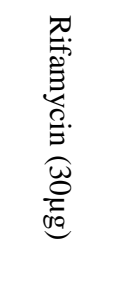 & 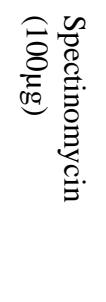 & 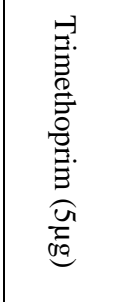 \\
\hline & & \multicolumn{12}{|c|}{ Number and percentage of sensitive strains } \\
\hline Cl. perfringens & 12 & $\begin{array}{c}3 / 12 \\
(25 \%)\end{array}$ & $\begin{array}{c}12 / 12 \\
(100 \%)\end{array}$ & $\begin{array}{l}12 / 12 \\
(100)\end{array}$ & $\begin{array}{c}3 / 12 \\
(25 \%)\end{array}$ & $\begin{array}{l}0 / 12 \\
(0 \%)\end{array}$ & $\begin{array}{c}6 / 12 \\
(50 \%)\end{array}$ & $\begin{array}{c}3 / 12 \\
(25 \%)\end{array}$ & $\begin{array}{c}12 / 12 \\
(100 \%)\end{array}$ & $\begin{array}{l}12 / 12 \\
(100 \%)\end{array}$ & $\begin{array}{l}0 / 12 \\
(0 \%)\end{array}$ & $\begin{array}{c}3 / 12 \\
(25 \%)\end{array}$ & $\begin{array}{c}3 / 12 \\
(25 \%)\end{array}$ \\
\hline Bacteroides spp. & 12 & $\begin{array}{l}0 / 12 \\
(0 \%)\end{array}$ & $\begin{array}{c}12 / 12 \\
(100 \%)\end{array}$ & $\begin{array}{c}4 / 12 \\
(33 \%)\end{array}$ & $\begin{array}{c}4 / 12 \\
(33 \%)\end{array}$ & $\begin{array}{l}0 / 12 \\
(0 \%)\end{array}$ & $\begin{array}{c}12 / 12 \\
(100 \%)\end{array}$ & $\begin{array}{c}8 / 12 \\
(67 \%)\end{array}$ & $\begin{array}{c}12 / 12 \\
(100 \%)\end{array}$ & $\begin{array}{c}12 / 12 \\
(100 \%)\end{array}$ & $\begin{array}{c}4 / 12 \\
(33 \%)\end{array}$ & $\begin{array}{l}0 / 12 \\
(0 \%)\end{array}$ & $\begin{array}{l}4 / 12 \\
(33 \%)\end{array}$ \\
\hline $\begin{array}{c}\text { Peptostreptococcus } \\
\text { anaerobius }\end{array}$ & 10 & $\begin{array}{l}0 / 10 \\
(0 \%)\end{array}$ & $\begin{array}{c}10 / 10 \\
(100 \%)\end{array}$ & $\begin{array}{c}6 / 10 \\
(60 \%)\end{array}$ & $\begin{array}{l}0 / 10 \\
(0 \%)\end{array}$ & $\begin{array}{l}0 / 10 \\
(0 \%)\end{array}$ & $\begin{array}{c}8 / 10 \\
(80 \%)\end{array}$ & $\begin{array}{c}6 / 10 \\
(60 \%)\end{array}$ & $\begin{array}{c}8 / 10 \\
(80 \%)\end{array}$ & $\begin{array}{c}10 / 10 \\
(100 \%)\end{array}$ & $\begin{array}{c}2 / 10 \\
(20 \%)\end{array}$ & $\begin{array}{l}0 / 10 \\
(0 \%)\end{array}$ & $\begin{array}{l}0 / 10 \\
(0 \%)\end{array}$ \\
\hline Total & 34 & $\begin{array}{c}3 / 34 \\
(8.8 \%)\end{array}$ & $\begin{array}{c}34 / 34 \\
(100 \%)\end{array}$ & $\begin{array}{c}22 / 34 \\
(64.7 \%)\end{array}$ & $\begin{array}{c}7 / 34 \\
(20.6 \%)\end{array}$ & $\begin{array}{l}0 / 34 \\
(0 \%)\end{array}$ & $\begin{array}{c}26 / 34 \\
(76.5 \%)\end{array}$ & $\begin{array}{l}17 / 34 \\
(50 \%)\end{array}$ & $\begin{array}{c}32 / 34 \\
(94.1 \%)\end{array}$ & $\begin{array}{l}34 / 34 \\
(100 \%)\end{array}$ & $\begin{array}{c}6 / 34 \\
(17.6 \%)\end{array}$ & $\begin{array}{c}3 / 34 \\
(8.8 \%)\end{array}$ & $\begin{array}{c}7 / 34 \\
(20.6 \%)\end{array}$ \\
\hline
\end{tabular}




\section{DISCUSSION}

Intestine and liver are considered to be the main target organs of anaerobic infection; intestine, because of its good vehicle for growth of the pathogenic bacteria and the production of its toxins. However the liver via the portal circulation is considered the core of the body metabolism and reflects the condition of the animal body in health and disease (El-Shahawy and Abd El-Gaied, 2006). Cl. perfringens is a known pathogen that causes enterotoxaemia in human and domestic animals, also is known to be a soil saprophytic and widespread in nature (sewage, faces, water and feeds) (Van Baelen and Devriese, 1987).

In the present study, bacteriological examination of aged female buffalo's liver samples revealed $71.64 \%$ were positive to anaerobic bacterial isolation (52.24 from hepatic affections and 19.40 from normal liver examined) (Table 1). It was thought that those bacterial isolates were found to play a role in the detected hepatic affections, since Zaki et al. (2000) found $77.8 \%$ of the examined liver samples of buffaloes were positive for obligatory anaerobic bacterial isolation. Failure for bacteriological isolation in 9 affected liver's buffalo samples, in the present study, may be due to other causes incriminated as viruses, molds or parasites. So, the etiology of liver infection is complex and multifactor which are either non-infectious or microbial determinates including bacteria, viruses and fungi (Blood and Radostitis, 1989).

Fasciola spp. play an important role in aiding microbial invasion to the infected animals either by transportation as a result of migration of immature liver flukes or depression of hepatic tissue resistance to be a good media for bacterial growth (Mousa, 1993; Osman, 2005; Sayed et al., 2008). All liver samples of aged female buffaloes infected with Fasciola $(\mathrm{n}=12)$ in the present work were positive for anaerobic isolation (Table 1). Moreover, parasitic infestation of liver may lower the resistance of the hepatic tissues and give chance for bacterial agents to attack as secondary invaders and produced their pathological lesions (Ahmed 1991; Mousa 1993).

As shown in Table 2, the incidence of mixed and single bacterial isolates was $41.7 \%$ and $58.3 \%$, respectively. The single and mixed infection of anaerobic isolates from buffalo's liver showing hepatic lesions recorded by Zaki et al. (2000) were $42.9 \%$ and $57.1 \%$.

In the present work as shown in Table 2, $\mathrm{Cl}$. perfringens was isolated in mixed form in an incidence of $29.2 \%$ (14 out of 48 liver samples were positive for anaerobic culture). High incidence (68.8\%) was obtained by Zaki, et al. (2000), which may be attributed to age of the slaughtered 
female buffaloes, change in hygienic measure, stress factors and immune status of the infected animal.

Cl. perfringens was recovered in mixed form with Bacteroides spp. and Peptostreptococcus anaerobius; this indicated that these microorganisms played a role in initiating hepatic affections in buffaloes (Tydon et al., 1980; Itman et al., 1989). Moreover, Fasciola infection plays an important role in stimulation of Clostridium infection especially $\mathrm{Cl}$. perfringens due to the changes which were attributed to toxic environment created by the organisms in liver tissues (Samad and Haque, 1987).

Clostridial species occur in a quiescent state in a considerable number of apparently normal livers and spleen of cattle and camel (Carter, 1984; Osman and Nour, 2002), in the present study $19.40 \%$ of the normal buffalo's liver were positive for anaerobic bacterial isolation (Table 1), and Cl. perfringens was isolated from two normal livers of aged female buffaloes with a percentage $4.2 \%$ (Table 2). $\mathrm{Cl}$. perfringens is one of the food poisoning microorganisms associated with enteric contamination (Silliker et al., 1980); also it was incriminated in food poisoning outbreaks due to liver consumption (Bryan, 1980).

Identification of the anaerobic pathogens in the present study cleared the isolation of Bacteroides spp.; Peptostreptococcus anaerobius; Cl. perfringens $(42.02 \%, 28.99 \%$ and $20.29 \%$, respectively); Cl. sordellii and $F$. necrophorum (5.8\% and $2.9 \%$ ) as shown in Table 3 . These were the most common anaerobic bacteria isolated from buffalos liver by Itman et al. (1989); El-Sayed et al. (1991) and Zaki et al. (2000).

Fusobacterium necrophorum was isolated in single form from two hepatic abscesses (4.2\%) (Table 3), this is similar to that obtained by Makhareta (1988); Ciftci et al. (1993); Abd El-Fattah, et al. (1995); El-Shahawy and Abd El-Gaied (2006), while Lichtenberg et al. (2005) detected it in $47 \%$. Fusobacterium necrophorum is considered to be one of the most common cause of hepatic abscesses (Blood and Radostitis, 1989).

From Table 4, it seems clear that the incidence of toxigenic Cl. perfringens was higher than non-toxigenic one. This result seemed to agree with the observation of Menazie (2000); Zaki et al. (2000). The virulence of the $\mathrm{Cl}$. perfringens is associated with production of several toxins (exotoxin and enterotoxin), among them four are known as the major lethal toxins $(\alpha ; \beta ; \mathrm{E}$ and I). Intravenous injection of these toxins to mice is highly lethal (Collier et al., 1998; Petit et al., 1999).

The present antimicrobial susceptibility testing (Table 5) showed that all tested isolates were highly sensitive to Ofloxacin and Ciprofloxacin (100\%) then Oxytetracycline $(94.1 \%)$, while the all tested strains were resistant Colistine, Spectinomycin and Amoxicillin. Non- spore forming 
anaerobes were susceptible to level of Oxytetracycline, but Gentamycin was ineffective (Prescott and Chirino-Trejo, 1984). Cl. perfringens was highly sensitive to Ciprofloxacin, but it was resistant to Colistine (Abd ElGwad and Abd El-Kader, 2001).

$\mathrm{Cl}$. Perfringens infections have a variety of origins including human and animal faeces, abattoirs, sewage and flies. Certain types of the organisms produce spores that resist boiling for four or more hours. If the spores are present as contaminants on raw meat they may resist boiling or stewing, and on slow cooling the spores will germinate into rapidly multiplying bacterial cells and produce large amounts of toxin (Gracey and Collins, 1992).

It can be concluded that livers of slaughtered aged female buffaloes are considered as hazardous source of mixed anaerobic bacteria especially that livers infected with Fasciola spp. In addition, $\mathrm{Cl}$. perfringens in the normal livers may constitute a public health hazard if consumed by human being.

\section{REFERENCES}

Abd El-Fattah, A.M.; Said, A.M. and Said, Ash, M. (1995): Bacteriological assessment of inflamed cattle livers with special view to hepatic abscesses. Assiut Vet. Med. J., 32 (64): 96-101.

Abd El-Gwad, A.M. and Abd El-Kader, H.A. (2001): The occurrence of Clostridium perfringens in the intestine of broiler chickens in Assiut Govrnorate. Assiut Univ. Bull. Environ. Res. 4(2): 13-22.

Ahmed, L.S. (1991): Incidence of hydatid disease in camels. Assiut Vet. Med. J., 32(63): 96-101.

Blood, D.C. and Radostitis, O.M. (1989): Veterinary Medicine. A textbook of the disease of cattle, sheep, pigs, goat and horse. $6^{\text {th }}$ ed. Bailliere Tindall.

Bryan, F.L. (1980): Food borne disease in the United States associated with meat and poultry. J. Food Prot., 43: 149.

Buogo, C.; Capaul, S.; Hani, H.; Frey, J. and Nicolet, J. (1995): Diagnosis of Clostridium perfringens type C. Enteritis in pig using a DNA amplification technique (PCR). Vet. Med. B. 42: 51-58.

Cater, G.R. (1984): Diagnostic Procedure in Veterinary Bacteriology and Mycology. $4^{\text {th }}$ ed. Charles, C. Thomas Publisher. Springfield. Illinois. U.S.A., PP. 181-195.

Ciftci, M.K.; Berkis and Turkutani, S.S. (1993): Incidence and pathology of liver abscesses in beef cattle. Veteriner-Fakultesi-Dergisi, SelcukUniversitesi, 9(1): 26-32. 
Collier, L.; Balows, A. and Sussman, M. (1998): Topley and Wilson's Microbiology and Microbial Infections $9^{\text {th }}$ ed., Vol. 2, New York, U. S. A. press.

Durham, A.E.; Smith, K.C.; Newton, J.R.; Hillyer, M.H.; Hillyer, L.L.; Smith, M.R. and Marr, C.M. (2003): Development and application of scoring system for prognosis evaluation of equine liver biopsies. Equine Vet. J.; 35(36): 534-540.

El-Sayed, Zienab, M.; El-Seedy, F.R.; Bardisy, M. and Kamel, S.M. (1991): A bacteriological study of sheep liver abscesses. Vet. Med. J. Giza, 39: 91-103.

El-Shahawy, H.S. and Abd El-Gaied, Sherein, S. (2006): Histopathological studies in young diarrheic claves due to some anaerobic bacteria. J.Egypt. Vet. Med. Ass. 66(4): 51-66.

Gracey, J.F. and Collins, D.S. (1992): Meat Hygiene. $9^{\text {th }}$ ed. Bailliere Tindall, London.

Hobbs, B.C. and Gilbert, R.J. (1969): Clostridium perfringens and Bacillus cereus infections in: Food borne Infections and Intoxications. Riemann, H. (ed.) PP. 131-137. Academic press, New York.

International Commission on Microbiological Specification for Food (ICMSF) (1986): Microorganisms in Food. VOL. 2 Sampling for Microbiological Analysis; Principles and Specific Applications. Black Well Scientific Publication, Oxford.

Itman, R.H.; Farrage, I. and Arab, R.M.A. (1989): A preliminary investigation on some anaerobic bacteria in the liver of buffaloes and camels. A Scientific Cong. of Fact. Vet. Med., Cairo, Univ., Egypt.

KamaKaraj, R.; Harris, D.L.; Songer, J.G. and Bors worth, B. (1998): Multiplex PCR assay for detection of Clostridium perfringens in feaces and intestinal content of pigs and swine feed. Vet. Microbiol. 63(1): 29-38.

Koneman, E.W.; Auen, S.D.; Dowell, V.R. and Sammers, H.M. (1988): Color Atlas and Textbook of Diagnosis Microbiology, $2^{\text {nd }}$ ed. J. B. Lip. Co. New York, London.

Lichtenberg, K.F.; Nagaraja, T.G.; Leipold, H.W. and Chengappa, M.M. (2005): Bacteriologic and histologic studies of hepatic abscesses in cattle. Department of Health \& Human Services Privacy Statement, Freedom of Information Act, Disclaimer, 32-41.

Mai, D.I. and Ezz El-Deen, Nashwa, A. (2003): Bacteriological and clinical studies on clostridial infection in cat fish. J. Egypt. Vet. Med. Ass. 63 (6): 103-114. 
Makhareta, M.A.M. (1988): Some studies on anaerobic microorganisms isolated from liver of buffaloes and camels. Thesis, M.V. Sci. Fac. Vet. Med. Cairo Univ.

Manecta, C.; Yalec, E. and Balish (2001): Bacterial intestinal flora associated with enterotoxaemia in Belgian Blue calves, Vet. microbial. J. Am. Vet. Med Assoc, 81 (1): 21.

Menazie, Ebtehal, M.M. (2000): Studies on intestinal clostridial infections in broiler chicken. M.V.Sc. Faculty of Vet. Med. Assiut Univ.

Mohamed, Sohair, Y.; Aly, S.M. and Enany, M.E. (2004): Pathological studies on clostridial infection among sheep in Suez Canal area. J. Egypt. Vet. Med. Ass. 64 (1): 163-174.

Mousa, M.M.I. (1993): Studies on liver fluke infestation in carcasses of food animals at Behera governorate, M.V. Sc. Thesis, fac. of Vet. Med. Alexandria Univ.

Niilo, L. (1986): Enteroxemic Clostridium perfringens. In Pathogenesis of Bacterial Infections in Animals ed. GYKS, CL and thoen, C. O. PP. 80-86. Iowa state University. U.S.A.

Onderdonk, A.B. and Allen, S.D. (1994): Clostridium in: Murray PR, Baron E.J., Pfaller MA, Tenover Fc, Yolken RH, editors, Manual of Clinical Microbiology $6^{\text {th }}$ ed. Washington DC: ASM press.

Osman, A.H. (2005): Pathological studies on some hepatic affections in horses. J. Egypt. Vet. Med. Ass. 65 (2): 91-109.

Osman, E.A. and Nour, M.H. (2002): Clostridial species in camel's edible offal. J. Egypt. Vet. Med. Ass. 62 (6c): 67-74.

Perelman, B.; Mints, S.; Zjut, M.; Kuttin, E. and Machny, S. (1991): An unusual Clostridium colinum infection in broiler chicken. Avian Pathology, 20: 475-480.

Petit, L.; Gibert, M. and Popoff, R. (1999): Clostridium perfringens: toxin type and geno type. Trends in Microbiology, 3: 104-110.

Prescott, J.E. and Chirino-Trejo, M. (1984): Non-sporeforming bacteria. In, Diagnostic Procedure in Veterinary Bacteriology and Mycology. $4^{\text {th }}$ ed. (eds. Cater, G. R.). Charles, C. Thomas Publisher. Springfield. Illinois. U.S.A. pp.140-160.

Quinn, P.J.; Markey, B.K.; Carter, M.E.; Donnlley, W.J. and Leonard, F.C. (2002): Veterinary Microbiology and Microbial Disease. Book Europe Limited, Wolfe Publishing.

Samad, M.A. and Haque, M.E. (1987): Clinical occurrence of infectious necrotic hepatitis in cattle of Bangladesh. Indian J. Animal Health, 26(1): 63-64. 
Sayed, S.M.; Sayed, Gehan, M. and El-Nisr, Neveen, A. (2008): Clinicodiagnostic studies on hepatic affections of aged buffaloes. Assiut Vet. Med. J. 54, 117: 310-328.

Siefert, HSH.; Bader, K.; Cyplik, J.; Gonan Zalez Salinas, J.; Roth, F.; Salinas Melendz, A. and Sukop, M. (1996): Environment incidence, aetiology, epizootiology and immunoprophylaxis of soilborne disease in North cast Mexico. J. Vet. Med. (B), 43: 593-606.

Silliker, J.H.; Elliot, R.P.; Baird-Parker, A.C.; Bryan, F.L.; Christian, J.H.P.; Clark, D.S.; Olson, J.C. and Roberts, J.R.T.A. (1980): Microbial Ecology of Foods II. Foods commodities. Academic Pres. New York, London, Toronto, Sydney, San Francisco.

Stringer, M.F.; Turnbull, P.C.B. and Gilbert, R.J. (1980): Application of serological typing to the investigating of outbreaks of Clostridium perfringens food poisoning 1970-1978. J. Hyg. Camb. 84: 443-456.

Tydon, R.A.; Chemma, A.H. and Mohammed, S.I. (1980): Microorganisms associated with abscesses of sheep and goats in the south of Iran. Am. J. Vet. Res., 41(5): 798-802.

Van Baelen, D. and Devriese, L.A. (1987): Presence of Clostridium perfringens exotoxin in intestinal samples from farm animals with diarrhea of unknown origin . J. Vet. Med. (B) 34, 713-716.

Yanny, Afaf, A. and Shalaby, Basma (2003): Evaluation of polymerase chain reaction for diagnosis of Clostridium perfringens enterotoxaemia in sheep. J. Egypt. Vet. Med. Ass. 63 (2): 129-135.

Zaki, E.R.; Afaf, A.Y.; Basma, S. and Nevine, M.S. (2000): Bacteria causing liver affection in buffaloes. J. Egypt. Vet. Med. Ass. 60 (2): 77-87. 
Assiut Vet. Med. J. Vol. 56 No. 127 October 2010 